\title{
Effect of supplementation of fish meal on growth and reproductive performance of crossbred heifers
}

\author{
M. S. Alam ${ }^{1}$, M. H. Rashid ${ }^{1}$, M. E. Uddin ${ }^{1}$ and M. Asaduzzaman ${ }^{2}$ \\ ${ }^{1}$ Department of Dairy Science, Bangladesh Agricultural University, Mymensingh-2202, Bangladesh and ${ }^{2}$ Department \\ of Dairy Science, Sher-e-Bangla Agricultural University, Dhaka, Email: bauah024@gmail.com
}

\begin{abstract}
The experiment was conducted at Bangladesh Agricultural University Dairy Farm to study the effect of fish meal (FM) on growth and reproductive performances of crossbred heifers. The experiment was designed into four treatment $\left(\mathrm{T}_{0}=0 \% \mathrm{FM} ; \mathrm{T}_{1}=5 \% \mathrm{FM} ; \mathrm{T}_{2}=7.5 \% \mathrm{FM}\right.$ and $\left.\mathrm{T}_{3}=10 \% \mathrm{FM}\right)$ groups having initial weight $231.33 \pm 32.39,241.00 \pm 46.29$, $198.66 \pm 58.53$ and $236.66 \pm 31.64 \mathrm{~kg}$, respectively. The average age of the animal is 2 years 9 month.

Results of the experiment revealed that there was a significant difference of FM on daily DMI (kg/d). In 90 days period, FM with rice straw based diet had significant effect on daily weight gain $(\mathrm{kg} / \mathrm{d})$ of crossbred heifers. DM, CP and CF digestibility $(\%)$ differ significantly $(p<0.05)$ among the group. But, the $E E$, Ash and NFE do not differ significantly. However, there is a tendency to increase digestibility when increase the FM among the Treatment group. Among this group $\mathrm{T}_{3}$ and $\mathrm{T}_{1}$ treatment showed $100 \%$ and $\mathrm{T}_{0}$ treatment $66 \%$ estrus and $\mathrm{T}_{1}$ did not showed estrus. Based on above findings, it may be concluded that supplementation of FM with Rice straw based diet can be the best options for feeding crossbred heifers to obtain better performances in terms of dry matter intake, digestibility, daily weight gain and reproductive performance especially estrus.
\end{abstract}

Keywords: Fish meal, Crossbred heifers, Rice straw, Growth, Reproduction

\section{Introduction}

Milk production is a livestock enterprise in which small-scale farmers can successfully engage in order to improve their livelihoods (Hemme et al., 2005). Raising young heifer was one of the most often neglected jobs on the dairy farm but one of the most important functions for economic status in a dairy farm. The future of herd's milk production begins before the calf born. How a heifer calf develops into her potential for milk production depends upon how well we raise and manage her. It was found that in order to obtain satisfactory production, Holstein heifers must gain an average of at least $1.6 \mathrm{lb} / \mathrm{d}$ from birth to calving and Jersey must gain $1.1 \mathrm{lb} / \mathrm{d}$ to attain the desired weight by 24 months of age (Moss et al., 1991). Nutrition draws the greatest attention because lack of proper nutrition can reduce the reproductive efficiency (Bearden and Fuquay, 1980). There is considerable evidence that specific nutrients, level of feeding, and body condition may influence fertilization of ova or ease of conception (Cole and Cupps, 1977). From a recent study (Akbar and Khaleduzzaman, 2009) on the availability of feeds and fodder, it is evident that the availability of nutrients are $73.11 \%$ DM, $18.49 \%$ DCP and $25.24 \%$ ME with deficits of $26.89 \%$ DM, $81.51 \%$ DCP and $74.76 \% \mathrm{ME}$, respectively. Fish meal (FM) is an important by-product of the fish industry. In general, FM is considered to be a high ruminal escape protein source. Fish meal is also carry importance of showing estrus in the aged heifer and daily body weight gain. So, supplementation of Rice straw-based diet with fish meal might be one of the solutions to overcome the above mentioned problem of rice straw-based diet. On the contrary to those reviews, the objectives are to determine the effect of fish meal with rice straw based diet on dry matter intake, digestibility, body weight gain, reproductive performances especially estrus and economic feasibility to rearing crossbred heifers by supplementing FM.

\section{Materials and Methods \\ Experimental site, duration and heifers}

The experiment was conducted at Bangladesh Agricultural University Dairy Farm (BAUDF), Bangladesh Agricultural University, Mymensingh, Bangladesh. For a period of 90 days from $1^{\text {st }}$ April to $30^{\text {th }}$ June, 2012 of which 15 days were adjustment period. Twelve crossbred heifers were selected for the experimental purposes on the basis of their age, body size and body condition. 


\section{Collection and preparation of feed ingredients}

Rice straw, Rice polish, wheat bran, fish meal, mustard oil cake, di-calcium phosphate, vitamin and salt were purchased. For the preparation of $100 \mathrm{~kg}$ of concentrate mixture, the following ingredients (Table 1) were mixed uniformly and kept in gunny bag for future uses.

Table 1. Composition of concentrate mixture

\begin{tabular}{|l|c|c|c|c|}
\hline $\begin{array}{c}\text { Ingredients of } \\
\text { concentrate mixture(Kg) }\end{array}$ & $\begin{array}{c}\text { Concentrate } \\
\text { mixture } \\
\text { without FM }\end{array}$ & $\begin{array}{c}\text { Concentrate } \\
\text { mixture (5\% } \\
\text { FM) }\end{array}$ & $\begin{array}{c}\text { Concentrate } \\
\text { mixture }(7.5 \% \\
\text { FM) }\end{array}$ & $\begin{array}{c}\text { Concentrate } \\
\text { mixture (10\% } \\
\text { FM) }\end{array}$ \\
\hline Rice police & 34.0 & 36.0 & 37.0 & 38.0 \\
\hline Wheat bran & 37.0 & 37.0 & 37.0 & 37.0 \\
\hline Fish meal & 0.0 & 5.0 & 7.5 & 10.0 \\
\hline Mustard oil cake & 24.0 & 17.0 & 13.5 & 10.0 \\
\hline Common salt & 4.0 & 4.0 & 4.0 & 4.0 \\
\hline Di-calcium phosphate & 1.0 & 1.0 & 1.0 & 1.0 \\
\hline
\end{tabular}

\section{Design, layout and others activities}

Crossbreds heifers of four treatment groups were denoted as $T_{0}$ (control), $T_{1}, T_{2}$, and $T_{3}$. The average body weight of the heifers are $231.33 \pm 32.39$ (Group- $T_{0}$ ), $241.00 \pm 46.29$ (Group- $T_{1}$ ), $198.66 \pm 58.53$ (Group- $\mathrm{T}_{2}$ ) and $236.66 \pm 31.64$ (Group- $\mathrm{T}_{3}$ ) $\mathrm{kg}$. Adjustment period of 15 days were carried out to habituate the animals with experimental feed. Concentrate mixture was supplied to the experimental heifers twice daily at 7.00 am and $12.45 \mathrm{pm}$. All the animals were supplied rice straw in ad libitum basis. All the animals had free access to the clean cold fresh drinking water for 24 hours. Feed intake was calculated after subtracting left over from the feed supplied. The heifers were weighed throughout the experimental period every 7 days interval. The total live weight gain was calculated by subtracting the initial weight from the final weight. A conventional digestibility trial was conducted for a period of 7 days with an object to see the digestibility of feed nutrients. During this time, all types of necessary data were maintained and calculate accordingly. Respective samples of feed and feces were subjected to chemical analysis for crude protein (CP), crude fiber (CF), ether extract (EE), ash and nitrogen free extract (NFE) accordingly the methods of AOAC (2004). The data were analyzed using the "SPSS" statistical programme to compute analysis of variance (ANOVA) for a Completely Randomized Design (CRD). Duncan's Multiple Range Test (DMRT) was also done for different parameter to compare the treatment means.

\section{Results and Discussion}

\section{Effect of FM on dry matter intake of crossbred heifers}

The result showed that daily DMI differs significantly $(p<0.05)$ by the FM with Rice straw based diet for 61-75 and 76-90 days interval period (Table 2). At 1-15, 15-30, 31-45 and 46-60 days interval period, the DMI was statistically insignificant. But treatment showed $T_{3}$ taken higher DMI followed by $T_{2}, T_{1}$ and $T_{0}$, respectively. During the 90 days experimental period, DMI intake also differs significantly among the treatment group. Here, treatment $T_{3}$ differs significantly to the $T_{2}, T_{1}$ and $T_{0}$. Whereas, $T_{0}$ and $T_{2}$ do not differ significantly. In every case, the result indicated that the higher DMI was found for $T_{3}$. Microbial activity of the rumen is also increased due to the presence of higher amount of FM. The nutrient availability of FM affects the DMI intake because the $T_{3}$ treatment contained higher FM i.e. 10\%, $T_{2}, T_{1}$ and $\mathrm{T}_{0}$ contained $7.5 \%, 5 \%$ and $0 \% \mathrm{FM}$, respectively. A recent study completed by Heravi at el. (2007) denoted that DMI was affected $(P<0.05)$ by diet, with the cows receiving $5 \%$ FM and $2.3 \%$ CaFOFA having the greatest intakes. In review of literature, also agree the result that DMI increase with supplying the higher (10\%) amount of FM. Another scientist (Petit and Flipot., 1992; Seoane et al., 1993; and Veira et al., 1994) agree that FM supplementation increased DMI in cattle fed silage diets. 
Table 2. Effect of FM on dry matter intake of crossbred heifers

\begin{tabular}{|c|c|c|c|c|c|}
\hline \multirow{2}{*}{ Days } & \multicolumn{4}{|c|}{ Mean $\pm \mathrm{SD}(\mathrm{DMI}, \mathrm{kg} / \mathrm{d})$} & \multirow{2}{*}{$\begin{array}{c}\text { Level of } \\
\text { significance }\end{array}$} \\
\cline { 2 - 5 } & $\mathrm{T}_{0}$ & $\mathrm{~T}_{1}$ & $\mathrm{~T}_{2}$ & $\mathrm{~T}_{3}$ & $\mathrm{NS}$ \\
\hline $1-15$ & $6.4 \pm 0.79$ & $7.4 \pm 0.64$ & $7.4 \pm 1.35$ & $7.7 \pm 1.06$ & $\mathrm{NS}$ \\
\hline $16-30$ & $7.0 \pm 0.94$ & $7.9 \pm 1.21$ & $6.9 \pm 0.95$ & $8.3 \pm 0.63$ & $\mathrm{NS}$ \\
\hline $31-45$ & $6.8 \pm 0.76$ & $7.9 \pm 0.14$ & $7.3 \pm 1.19$ & $8.2 \pm 1.04$ & $\mathrm{NS}$ \\
\hline $46-60$ & $7.1 \pm 1.00$ & $8.0 \pm 1.19$ & $8.1 \pm 1.13$ & $9.0 \pm 0.56$ & $*$ \\
\hline $61-75$ & $6.6^{\mathrm{a}} \pm 1.04$ & $7.0^{\mathrm{a}} \pm 1.00$ & $8.5^{\mathrm{b}} \pm 0.64$ & $9.1^{\mathrm{c}} \pm 0.54$ & ${ }^{\mathrm{a}}$ \\
\hline $76-90$ & $6.6^{\mathrm{a}} \pm 0.93$ & $7.7^{\mathrm{b}} \pm 0.40$ & $6.7^{\mathrm{a}} \pm 1.39$ & $8.9^{\mathrm{c}} \pm 0.55$ & $7^{\mathrm{a}}$ \\
\hline $1-90$ & $6.7^{\mathrm{a}} \pm 0.65$ & $7.7^{\mathrm{b}} \pm 0.65$ & $7.5^{\mathrm{a}} \pm 1.01$ & $8.5^{\mathrm{c}} \pm 0.67$ & ${ }^{2}$ \\
\hline
\end{tabular}

NS $=$ Non- significant $(P>0.05)$

* $\quad=5 \%$ Level of significance $(P<0.05)$

$\mathrm{SD}=$ Standard deviation

\section{Effect of FM on daily weight gain of crossbred heifers}

The whole experimental period of 90 days was divided into six sub-periods denoted as 1-15, 16-30, 31$45,46-60,61-75$ and 76-90 days (Table 3). The obtained results showed that the daily weight gain of crossbred heifers fed Rice straw based diet with FM at 16-30, 31-45, 46-60 and 76-90 days interval period differs significantly at $p<0.05$ and $51-75$ days experimental period differs at $p<0.01$. The $1-15$ days of the experimental period, daily body weight gain does not differ significantly among treated animal groups fed rice straw based diet with FM. The daily weight gain $(\mathrm{g} / \mathrm{d})$ of overall 90 days of experimental period was 251.8, 225.9, 262.9 and 440.7 for the treatment group $T_{0}, T_{1}, T_{2}$ and $T_{3}$, respectively. The animals fed FM with rice straw based diet showed better daily gain which might be increasing utilization of nutrients by higher plane of feeding. Isabelle et al. (1990) observed that live-weight gain of heifers, were significantly higher at the higher plane of feeding through FM with straw based diet. Another study was conducted by Rocha et al. (1995) showed that bulls assigned to fed FM had higher total weight gain. A linear effect of FM on average daily gain in steers fed grass silage supplemented with FM up to $6.4 \%$ of dietary DM concluded by Veira et al. (1994). Mandell et al. (1997) observed that the daily gains in cattle fed $5 \%$ FM diet exceeded $(P=0.01)$ those in cattle fed $10 \% \mathrm{FM}$, resulting in heavier $(P=0.03)$ BW before slaughter.

Table 3. Effect of FM on daily body weight gain of crossbred heifers

\begin{tabular}{|c|c|c|c|c|c|}
\hline \multirow{2}{*}{ Parameters(days) } & \multicolumn{4}{|c|}{ Mean \pm SD $(g / d)$} & \multirow{2}{*}{$\begin{array}{c}\text { Level of } \\
\text { significance }\end{array}$} \\
\hline & $\mathrm{T}_{0}$ & $\mathrm{~T}_{1}$ & $\mathrm{~T}_{2}$ & $\mathrm{~T}_{3}$ & \\
\hline $1-15$ & $244.4 \pm 38.4$ & $200.0 \pm 66.6$ & $255.5 \pm 50.9$ & $288.8 \pm 38.4$ & NS \\
\hline $16-30$ & $255.5^{\mathrm{a}} \pm 50.9$ & $188.8^{\mathrm{a}} \pm 50.9$ & $255.5^{\mathrm{a}} \pm 50.9$ & $477.7^{b} \pm 19.2$ & * \\
\hline $31-45$ & $255.5^{\mathrm{a}} \pm 50.9$ & $188.8^{\mathrm{a}} \pm 50.9$ & $255.5^{\mathrm{a}} \pm 50.9$ & $477.7^{b} \pm 19.2$ & * \\
\hline $46-60$ & $244.4^{\mathrm{a}} \pm 19.2$ & $233.3^{\mathrm{a}} \pm 33.3$ & $266.6^{\mathrm{a}} \pm 33.3$ & $455.5^{b} \pm 69.3$ & * \\
\hline $61-75$ & $255.5^{\mathrm{a}} \pm 50.9$ & $233.3^{a} \pm 33.3$ & $255.5^{\mathrm{a}} \pm 50.9$ & $522.2^{\mathrm{b}} \pm 50.9$ & ** \\
\hline $76-90$ & $244.4^{\mathrm{a}} \pm 38.4$ & $277.7^{\mathrm{a}} \pm 19.2$ & $255.5^{a} \pm 50.9$ & $444.4^{b} \pm 38.4$ & * \\
\hline $1-90$ & $251.8^{\mathrm{a}} \pm 23.1$ & $225.9^{a} \pm 25.6$ & $262.9^{a} \pm 44.9$ & $440.7^{b} \pm 16.9$ & ** \\
\hline
\end{tabular}

NS $=$ Non- significant $(P>0.05)$

$* *=1 \%$ Level of significance $(P<0.05)$

* $\quad=5 \%$ Level of significance $(P<0.05)$

$\mathrm{SD}=$ Standard deviation 


\section{Effect of FM on digestibility of crossbred heifers}

Here, DM, CP and CF digestibility differ significantly $(p<0.05)$ among the treatment group and EE, Ash and NFE are not statistically significant but all nutrients showed that a tendency to increase digestibility when increasing the FM to the animal among the Treatment $\left(T_{1}=5 \%, T_{2}=7.5 \%\right.$ and $\left.T_{3}=10 \%\right)$ group (Table 4). The causes of increase digestibility might be good source of available nutrients that easily used by the rumen microbes and synthesized rumen microbial protein and other substances. Oldham and Smith (1982) suggested that growing cattle weighing more than $200 \mathrm{~kg}$ and with adequate energy intake can meet their protein requirements from the microbial protein synthesized in the rumen. The use of dietary nitrogen increased through the high digestible silage (Steen, 1985). In contrast, responses to FM were positive (Garstang et al., 1979; Thomas et al., 1980; Garstang, 1981; Gill and England, 1981, 1983; Owen and Ochoa, 1982; Ochoa and Owen, 1983) when calves were fed diets based on grass silages of poor quality (containing $9 \% \mathrm{CP}$ on DM basis, $17 \% \mathrm{NH} 3 \mathrm{~N}$ of total $\mathrm{N}$ and having $60 \%$ or less $\mathrm{OM}$ digestibility) or of medium quality (containing $12 \%$ CP on DM basis, $10 \% \mathrm{NH} 3 \mathrm{~N}$ of total $\mathrm{N}$ and having $65 \%$ OM digestibility). Results obtained with growing, finishing beef cattle fed medium quality silage also indicated that responses to FM supplementation were positive (Kirby et al., 1983, 1985).

Table 4. Effect of FM on digestibility of crossbred heifers

\begin{tabular}{|l|c|c|c|c|c|}
\hline \multirow{2}{*}{\multicolumn{1}{c|}{ Parameters }} & \multicolumn{4}{c|}{ \% digestibility $\pm \mathrm{SD}$} & \multirow{2}{*}{$\begin{array}{c}\text { Level of } \\
\text { significance }\end{array}$} \\
\cline { 2 - 5 } & $\mathrm{T}_{0}$ & $\mathrm{~T}_{1}$ & $\mathrm{~T}_{2}$ & $\mathrm{~T}_{3}$ & $*$ \\
\hline Dry matter & $53.3^{\mathrm{a}} \pm 0.57$ & $55.0^{\mathrm{a}} \pm 1.00$ & $57.6^{\mathrm{b}} \pm 3.51$ & $59.6^{\mathrm{c}} \pm 1.52$ & $*$ \\
\hline Crude protein & $52.8^{\mathrm{a}} \pm 0.78$ & $53.7^{\mathrm{a}} \pm 2.03$ & $57.0^{\mathrm{b}} \pm 1.00$ & $56.7^{\mathrm{b}} \pm 2.53$ & $*$ \\
\hline Crude fiber & $55.2^{\mathrm{a}} \pm 1.50$ & $58.2^{\mathrm{a}} \pm 2.09$ & $60.0^{\mathrm{a}} \pm 1.00$ & $63.8^{\mathrm{b}} \pm 4.01$ & $\mathrm{NS}$ \\
\hline Ether extract & $53.9 \pm 0.85$ & $54.6 \pm 2.51$ & $55.0 \pm 2.00$ & $54.6 \pm 1.52$ & $\mathrm{NS}$ \\
\hline Ash & $15.0 \pm 2.00$ & $14.6 \pm 1.53$ & $16.0 \pm 2.64$ & $17.6 \pm 3.05$ & $\mathrm{NS}$ \\
\hline Nitrogen free extract & $54.8 \pm 3.05$ & $55.5 \pm 3.50$ & $52.4 \pm 5.39$ & $54.3 \pm 2.98$ & \\
\hline
\end{tabular}

NS $=$ Non- significant $(P>0.05)$

* $=5 \%$ Level of significance $(P<0.05)$

$\mathrm{SD}=$ Standard deviation

\section{Effect of FM on estrus of crossbred heifers}

In this experiment, the crossbred heifer was aged and did not showing heat in long time. This why, experiment was set by this animal to increase the reproductive performance specifically estrus. In this experiment, four treatment group and each group contain 3 heifers. In, $T_{0}$ group 2 animals showed estrus, $\mathrm{T}_{1}$ group showed estrus $3, \mathrm{~T}_{2}$ group showed estrus 0 and $\mathrm{T}_{3}$ group showed estrus 3 . Among those groups $\mathrm{T}_{3}$ and $\mathrm{T}_{1}$ treatments showed $100 \%$ and $\mathrm{T}_{0}$ treatment $66 \%$ estrus and $\mathrm{T}_{1}$ did not showed estrus. It may be the nutrient point of view, the FM containing diet have a balance formulation for reproduction such as conception, pregnancy, estrus etc. Burke et al. (1997) observed that every 0.5-unit increase in BCS at 58 d PP for cows synchronized twice, the rate of estrus detection increased more. Although cows with greater DMI have lower progesterone concentration, improving energy status by enhancing DMI increases peripheral concentrations of progesterone (Britt, 1994; Villa-Godoy et al., 1988), which benefits reproduction. Staples et al. (1998b) reviewed several studies in which included FM in the diet of dairy cows. Feeding FM increased reproductive performance specially conception or pregnancy rates. In the review, it is recommended that the FM affect the reproductive performance specifically conception or pregnancy rates of cattle. But in this study, it is concluded that FM affect in showing of reproductive performance specifically estrus.

\section{Cost-Benefit Analysis}

Profit is the main goal of any enterprise and it can be manipulated either by reducing input or increasing the output to an optimum level. As feed cost comprising of 55-70 \% of the total cost of livestock rearing, so the effective utilization of feeds and fodder can reduce feed cost as well as reducing input cost. Most 
processes involve the use of considerable amounts of fuel and labor cost and so, the cost-benefit comparisons are important for any processing methods adopted for processing the feeds and fodder. If the processing method is not profitable, it would be wise to avoid such method of processing of the feedstuffs. In case of heifer rearing, the most visible output is body weight gain, and in cage of aged heifer that do not show the heat regular, but when those heifer showing heat regularly after treatment then it is the important criteria for cost-analysis in long term. Along with feed cost, labor is another most important component of input and other components of input that we can avoid grossly while costing, are cost of medicine, depreciation cost etc. The cost-benefit analysis of the present research work is shown in the Table 5. During the trial period the local market price of meat was Tk. $260 / \mathrm{Kg}$. The cost of concentrate mixture (rice polish, wheat bran, mustard oil cake, FM, DCP) is tk per kg 24-26 with or without FM. From the table 4.5, it appears that the output per unit of input in treatment combination $\mathrm{T}_{3}$ was highest among four treatment groups. So, the treatment group $\mathrm{T}_{3}$ is economically more viable than other three groups. Finally, it can be said that feeding of FM $(10 \%)$ is more economic than $5 \%, 7.5 \%, 0 \%$, respectively.

\section{Table 5. Cost-benefit analysis}

\begin{tabular}{|l|c|c|c|c|}
\hline \multirow{2}{*}{\multicolumn{1}{|c|}{ Cost Item (Tk./d/animal) }} & \multicolumn{4}{c|}{ Treatment Combinations } \\
\cline { 2 - 4 } & $\mathrm{T}_{0}$ & $\mathrm{~T}_{1}$ & $\mathrm{~T}_{2}$ & $\mathrm{~T}_{3}$ \\
\hline Rice straw & 27.45 & 31.42 & 28.4 & 31.39 \\
\hline Concentrate mixture & 19.55 & 19.58 & 19.6 & 19.61 \\
\hline Labor cost & 6.0 & 6.0 & 6.0 & 6.0 \\
\hline Total Input & 53.00 & 57.37 & 54.00 & 57.00 \\
\hline Out Put of Body weight gain & 65.00 & 59.80 & 68.00 & 115.00 \\
\hline Total Out Put & 65.00 & 59.80 & 68.00 & 115.00 \\
\hline Cost-Benefit Ratio & $01: 01.2$ & $01: 01.0$ & $01: 01.3$ & $01: 02.1$ \\
\hline
\end{tabular}

From the above discussion, it can be concluded that feeding of FM (10\% inclusion level) is more economical than feeding of FM 5 and $7.5 \%$.

\section{Conclusion}

In dairy farming, the heifer stock plays a key role in determining the herd size, the number of animal to be culled, decision on reproductive management and the overall return of the enterprise. In other words, heifer conveys a very important economic role in dairy industry. But, feed is a major constraint and cost involving factors to rearing the heifers beneficially. In Asian sub-continent, Rice straw is the major feed for feeding animal. Whereas the feeding value of Rice straw is not sufficient for the animal. So, need to conduct a study to supplementation of FM with Rice straw to increase the digestibility and availability of nutrients to promote the growth and reproductive performance of animal. Based on conducted research findings, it might be concluded that supplementation of FM with rice straw based diet can be the best options for feeding crossbred heifers to obtain better performances in terms of dry matter intake, digestibility, daily weight gain and reproductive performance especially estrus.

\section{References}

Akbar, M.A. and Khaleduzzaman, A.B.M. 2009. Feeds and feeding: survey of feedstaffs availability. Dairy Nutrition Handbook for Bangladesh. Pulished by American Soybean Association (ASA). New Delhi. India. pp. 22

Britt, J.H. 1994. Follicular development and fertility: Potential impacts of negative energy balance. In Procedings of National Reproduction Symposium. Pittsburgh, PA. pp. 103-112.

Burke, J.M., Staples, C.R., Risco, C.A., De La Sota, R.L. and Thatcher, W. W. 1997. Effect of ruminant grade menhaden fish meal on reproductive and productive performance of lactating dairy cows. Journal of Dairy Science. 80(12): 3386-98.

Cole, H.H. and Cupps, P.T. 1977. Reproduction in Domestic Animals. Third Edition. Academic Press Inc. pp. 665.

Garstang, J.R. 1981. Silage supplements for calves. Animal Production. 32:355.

Gill, M. and England, P. 1981. The effect of type of protein supplement on voluntary intake and nitrogen retention in calves given grass silage. Animal Production. 32:355. 
Gill, M. and England, P. 1983. The effect of level of fish meal and sucrose supplementation on the voluntary intake of shge and liveweight gain in young cattle. Animal Production. 36:513.

Hemme, T., Garcia, O. and Khan, A.R. 2005. A review of milk production in Bangladesh with particular emphasis on small-scale producers. Pro-Poor Livestock Policy Initiative (PPLPI). pp. 5

Heravi, A.R.M., Gilbert, R.O., Overton, T.R., Bauman, D.E. and Butler, W.R. 2007. Effects of Feeding Fish Meal and n-3 Fatty Acids on Milk Yield and Metabolic Responses in Early Lactating Dairy Cows. Journal of Dairy Science. 90:136-144.

Isabelle, O., Smith, T., Gill, M., Cammell, S.B. and Yarrow, N.W. 1990. The effect of fish meal supplementation of a straw-based diet on growth and calorimetric efficiency of growth in heifers. British Journal of Nutrition. 64, 639-651.

Mandell, I.B., Buchanan-Smith, J.G., Holub, B.J. and Campbell, C.P. 1997. Effects of fish meal in beef cattle diets on growth performance, carcass characteristics, and fatty acid composition of longissimus muscle. Journal of Animal Science. 75:910-919.

Moss, B.R., Coleman, D.A. and Floyd, J. 1991. Feeding and management of the dairy calf: birth to 6 months. Animal Dairy Science, Auburn University. Annual Report. pp. 609.

Ochoa, C, and Owen, E. 1983. Energy and protein supplementation of grass silage for Friesian steers: effect on performance from 2 to 7 months of age on subsequent compensatory growth. Animal Production. 36:536.

Oldham, J.D. and Smith, T. 1982. Rotein-energy interrelationships for growing and for lactating cattle. In: E. L. Miller, I. H. pike and AJ.H. Van Es in Contribution of Feedstuffs for Ruminants: Application to Feed Formulation. Pp. 103-130.

Owen, E. and Ochoa, C. 1982. Energy and protein supplementation of grass silage for Friesian steers: effect on performance from 4 to 7 months of age and on subsequent compensatory growth. Animal Production. 34:387.

Petit, H.V. and Flipot, P.M. 1992. Source and feeding level of nitrogen on growth and carcass characteristics of beef steers fed grass as hay or silage. Journal of Animal Science. 70:867.

Rocha, A., Carpena, M., Triplett, B., Forrest, D.W. and Randel, R.D. 1995. Effect of ruminally undegradable protein from fish meal on growth and reproduction of peripuberal brahman bulls. Journal of Animal Science. 73:947-953.

Seoane, J.R., Amyot, A., Christen, A.M. and Petit, H.V. 1993. Performance of growing steers fed either hay or silage supplemented with canola or fish meal. Canadian Journal of Animal Science. 73:57.

Staples, C.R., Mattos, R.A., Risco, C.A. and Thatcher, W. W. 1998b. Feeding fish meal may improve cow fertility rates. Feedstuffs. 70(2):12-13.

Steen, R.W.J. 1985. Protein supplementation of silage-based diets for calves. Animal Production. 41:293.

Thomas, C., Gill, M. and Austin, A.R. 1980. The effect of supplements of fishmeal and lactic acid on voluntary intake of silage by calves. Grass Forage Science. 35:275.

Uddin. M.E. 2012. Effect of particle size of para grass and maize grain on intake, digestibility and growth performance of crossbred heifers. MS thesis. Department of Dairy Science, Bangladesh Agricultural University, Mymensingh-2202. Bangladesh.

Veira, D.M., Butler, G., Proulx, J.G. and Poste, L.M. 1994. Utilization of grass silage by cattle: effect of supplementation with different sources and amounts of protein. Journal of Animal Science. 72:1403.

Villa-Godoy, A., Hughes, T.L., Emery, R.S., Chaplin, T.L. and Fogwell, R.L. 1988. Association between energy balance and luteal function in lactating dairy cows. Journal of Dairy Science. 71:1063-1069. 